\title{
Is the Antitumor Property of Trypanosoma cruzi Infection Mediated by Its Calreticulin?
}

\author{
Galia Ramírez-Toloza ${ }^{1 *}$, Paula Abello ${ }^{2}$ and Arturo Ferreira ${ }^{2 *}$ \\ ${ }^{1}$ Faculty of Veterinary Medicine and Livestock Sciences, University of Chile, Santiago, Chile, ${ }^{2}$ Program of Immunology, \\ Faculty of Medicine, Institute of Biomedical Sciences (ICBM), University of Chile, Santiago, Chile
}

\section{OPEN ACCESS}

Edited by: Alexandre Morrot, Federal University of Rio de Janeiro, Brazil

Reviewed by: Graciela Alicia Cremaschi, Institute of Biomedical Research (BIOMED), Argentina

Celio Geraldo Freire De Lima, Federal University of Rio de Janeiro, Brazil

*Correspondence: Galia Ramírez-Toloza galiaram@uchile.cl; Arturo Ferreira aferreir@med.uchile.cl

Specialty section: This article was submitted to Microbial Immunology, a section of the journal Frontiers in Immunology

Received: 01 June 2016 Accepted: 27 June 2016 Published: 11 July 2016

Citation:

Ramírez-Toloza G, Abello P and Ferreira A (2016) Is the Antitumor

Property of Trypanosoma cruzi Infection Mediated by Its Calreticulin?

Front. Immunol. 7:268.

doi: 10.3389/fimmu.2016.00268
Eight to 10 million people in 21 endemic countries are infected with Trypanosoma cruzi. However, only $30 \%$ of those infected develop symptoms of Chagas' disease, a chronic, neglected tropical disease worldwide. Similar to other pathogens, T. cruzi has evolved to resist the host immune response. Studies, performed 80 years ago in the Soviet Union, proposed that T. cruzi infects tumor cells with similar capacity to that displayed for target tissues such as cardiac, aortic, or digestive. An antagonistic relationship between T. cruzi infection and cancer development was also proposed, but the molecular mechanisms involved have remained largely unknown. Probably, a variety of $T$. cruzi molecules is involved. This review focuses on how $T$. cruzi calreticulin (TcCRT), exteriorized from the endoplasmic reticulum, targets the first classical complement component $\mathrm{C} 1$ and negatively regulates the classical complement activation cascade, promoting parasite infectivity. We propose that this C1-dependent TcCRT-mediated virulence is critical to explain, at least an important part, of the parasite capacity to inhibit tumor development. We will discuss how TCCRT, by directly interacting with venous and arterial endothelial cells, inhibits angiogenesis and tumor growth. Thus, these TcCRT functions not only illustrate T. cruzi interactions with the host immune defensive strategies, but also illustrate a possible co-evolutionary adaptation to privilege a prolonged interaction with its host.

Keywords: calreticulin, Trypanosoma cruzi, trypomastigotes, complement system, C1q, cC1qR, tumor growth, immune response

\section{INTRODUCTION}

Trypanosoma cruzi (the protozoan agent of Chagas' disease) cell infection is preceded by a variety of molecular interactions (1). Of relevance is the generation of a synapsis involving parasite endoplasmic reticulum (ER)-resident T. cruzi calreticulin (TcCRT) that, after translocation, interacts with complement component $\mathrm{C} 1 . \mathrm{C} 1$ is then inactivated and recognized by $\mathrm{cClqR}$ (a membrane form of mammalian CRT). The complement system, an important arm of innate and adaptive immune responses, is thus inhibited and parasite infectivity increased.

A significant decrease in experimental tumor growth is observed in experimental animals treated with recombinant TcCRT (rTcCRT) or infected with T. cruzi. A unifying molecular basis for these apparently unrelated phenomena is proposed herein. These molecular interactions do provide benefits for both the host and the parasite.

Through evolution, microbial agents have developed different mechanisms to resist the host immune response. In apparently unrelated strategies, some infectious agents elicit antitumor 
immune responses, leading to inhibition of cancer progression (2). Although these antitumor effects have been reported for several decades now, for a variety of infections, information on pathogen molecules involved is scarce (3).

Eight to 10 million people in 21 endemic countries are infected with T. cruzi. In about $30 \%$ of those infected, manifests, Chagas' disease, a worldwide neglected tropical chronic illness $(4,5)$. The disease, originally endemic in Latin America, is now global, mainly because of migrations to USA, Canada, Europe, Oceania, and Asia (6), where transmission is mainly through blood transfusions, organ transplants, or congenital (7).

Eighty years ago, it was proposed that T. cruzi possesses an anticancer activity. Several T. cruzi strains displayed growth inhibitory effects over multiple transplanted or spontaneous tumors, in animal experimental models and humans $(8,9)$. This property was attributed to a "toxic substance" secreted by the parasite $(10,11)$. This "toxin" reduced pain, tumor growth, bleeding, and local inflammation in humans affected by a variety of tumors (12).

Chronically infected rats are more resistant to a carcinoma induced by 1,2-dimethylhidrazyne (9), and T. cruzi has a tropism for tumor cells, suggesting an antagonistic relationship between Chagas' disease and cancer development (8). Elemental Darwinian reasoning allows us to propose that, if host survival is favored, chances for improved parasite persistence are evident.
Some authors have proposed that tumor and parasites compete for nutrients with consequent inhibition of tumor growth (13). However, this hypothesis is not entirely satisfactory since tumor growth is a multistep and complex process involving development of new blood vessels (angiogenesis) that provide the tumor with the necessary nutrients, oxygen, and means for waste removal (14). Other investigators have demonstrated, using a recombinant non-pathogenic T. cruzi clone as vector of a testis tumor antigen, the activation of $\mathrm{T}$ cell-mediated immunity. This specific cell immunity could delay tumor development in infected mice (15). In this work, it would have been important to define whether the non-pathogenic T. cruzi clone used translocatesexternalizes its CRT. Non-infective epimastigotes are strongly impaired in their capacity to translocate this chaperone (16). Moreover, hemiallelic TcCRT KO, wild type, and transgenic parasites, respectively carrying one, two, and three TcCRT gene copies, express increased levels of the protein, in vitro resistance to human complement, and higher infectivity $(16,17)$.

Most likely, multiple parasite molecules and mechanisms are involved in the tumor resistance mediated by T. cruzi infection. Understanding these mechanisms may contribute to identify new therapeutic targets against cancer and Chagas' disease.

Our laboratory has been working for more than 20 years now with TcCRT, a multifunctional ER-resident protein that the parasite translocates to the external milieu (as depicted in Figures 1A,B). TcCRT is involved in a multiplicity of

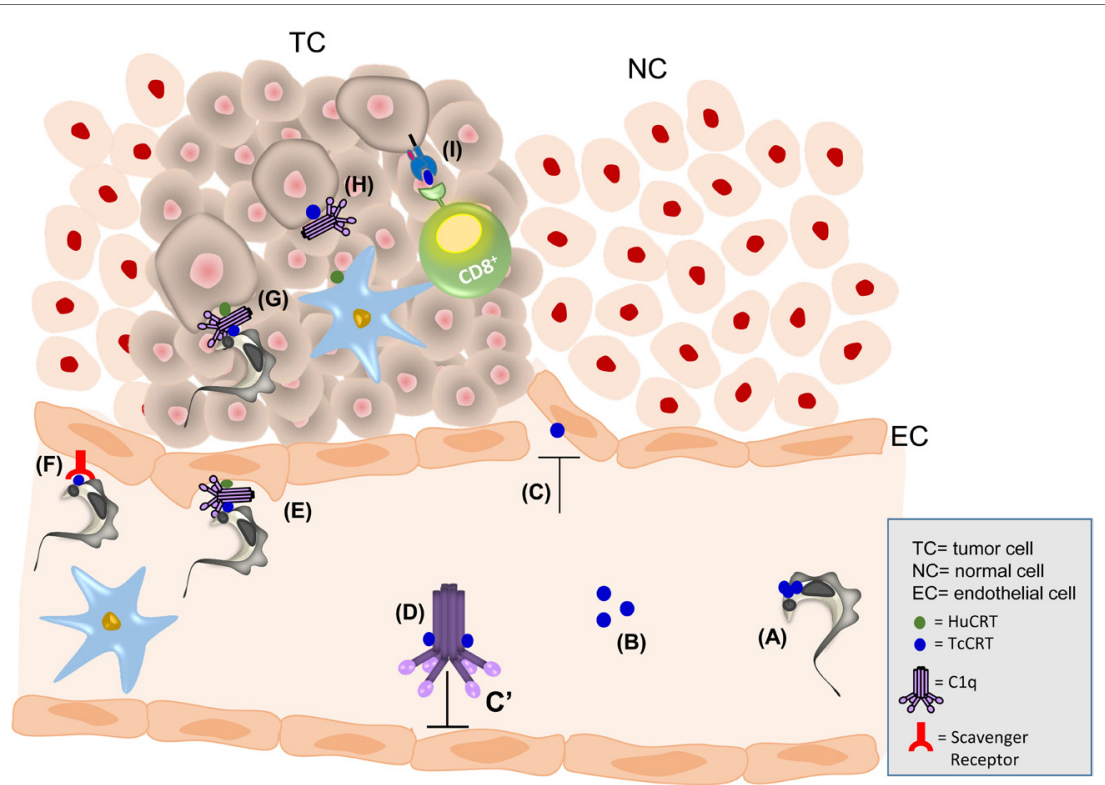

FIGURE 1 | The antitumor effect of $\boldsymbol{T}$. cruzi infection may be explained by TcCRT. TCCRT is exposed on the parasite surface (A) and secreted (B). TcCRT inhibits angiogenesis (C) and the activation of the classical pathway of the complement system through C1 inactivation (D). TcCRT, present on the parasite surface, recruits C1. On the EC membrane, a trimolecular synapse is formed by HuCRT/C1q/TcCRT. This interaction increases the infectivity process (E). TcCRT is also recognized by SRs on ECs, promoting infectivity (F). The HuCRT/C1q/TcCRT interaction can also promote T. cruzi infectivity in TCs (G). Moreover, TcCRT could mediate induction of an anamnestic antitumor immune response. Parasite could translocate TcCRT bound to the tumor cell with subsequent capture of host $\mathrm{C} 1$ (H). This C1 will be recognized by HuCRT present on an antigen-presenting cell (APC), followed by internalization of this complex. Among many other possibilities, APCs will cross-process TcCRT, and specific peptides from this parasite protein will be loaded onto MHC I molecules. APCs will enter the regional lymph node and present these nTcCRT-specific peptides to cytotoxic T lymphocytes, thus leading to their activation. These CD8 ${ }^{+}$cytotoxic T lymphocytes will leave the lymph node and kill tumor cells that also present TcCRT-derived peptides (I). 
host-pathogen interactions. Thus, TcCRT is a potent virulence factor that inhibits the angiogenesis and a likely responsible, for at least in important part, of the antitumor effects of T. cruzi infection.

\section{IN EUKARYOTES, CALRETICULIN, AN ER-RESIDENT CHAPERONE PROTEIN, MEDIATES ANTITUMOR PROPERTIES}

Calreticulin (CRT) is a $45 \mathrm{kDa}$ protein, mainly residing in the ER (18). CRT participates in a variety of physiological and pathological processes in different cellular types (19). Thus, CRT contributes in multiple physiological processes such as control of glycoprotein folding quality system and binding to monoglucosylated high mannose glycans (20). Moreover, CRT is involved in quality control process during protein synthesis, including integrins, surface receptors, and transporters (21), and it is considered as an intracellular $\mathrm{Ca}^{2+}$ regulator (22).

Calreticulin is also found in the cytosol, nucleus, secretory granules, on the plasma membrane, and free in the extracellular milieu (18), accelerating cutaneous wound healing (23-25) and regulating cell adhesion by interacting with the cytosolic tail of the integrin alpha subunit (18); nuclear export of some steroid hormone receptors (26-28) and the stability or translation of a variety of RNAs (29-33). CRT is an mRNA binding protein that regulates mRNA stability (19).

Calreticulin also participates in the immune response against apoptotic cancer cells (34-38), and surface exposure of CRT participates as an "eat me" signal required for phagocytosis on dying tumor cells (39). Tumor tissues express significant higher levels of CRT compared to normal tissues (40). Indeed, its expression is related to the clinical stage and lymph node metastasis in several types of cancer $(41,42)$.

Over 40 functions have been described for human CRT (HuCRT) (43). These functions reside in three different domains: globular N-terminal $(\mathrm{N})$, proline-rich $(\mathrm{P})$, and acidic C-terminus (18). HuCRT and its N-terminal fragment bind laminin (44) with antiangiogenic properties in vitro and in vivo $(45,46)$ and inhibit the growth in several tumor models (47-49).

Vasostatin, a CRT 180 amino acid N-terminal fragment, is an endogenous inhibitor of angiogenesis and suppressor of tumor growth. It inhibits vascular endothelial growth factor (VEGF)-induced endothelial cell (EC) proliferation and tube formation in Matrigel and induces cell apoptosis under oxygen deprivation (50).

Calreticulin is present in humans (51), insects (52, 53), nematodes (54-57), protozoans (58-61), and plants (62). A high identity is shared among CRTs from different species. Thus, Onchocerca volvulus, Schistosoma mansoni, and Leishmania donovani share $50 \%$ of the identity in amino acid sequence with HuCRT.

Examples of important evasive strategies performed by CRTs from different parasite species are Amblyomma americanum [secretes CRT during the feeding process (63)] and Schistosoma cercariae [uses CRT in the penetration of gland cells or skin and parasite migration (54)].

\section{HOW DOES T. CRUZI CALRETICULIN PARTICIPATE IN THE HOST-PARASITE INTERPLAY?}

Given the important pleiotropic HuCRT behavior, the CRT model opens interesting research opportunities on how this protein, alone or interacting with others, intervenes in the host-parasite interactions.

For 25 years now, our laboratory has worked with TcCRT. This protein is coded by only one gene with a variable number of copies whose involvement in TcCRT expression will depend on the T. cruzi clone and strain studied (unpublished data). A TcCRT gene was cloned, sequenced, and expressed in our laboratory in 1991 (58). We identified variable low plasma levels of anti-native TcCRT antibodies in T. cruzi-infected humans (64), thus revealing the immunogenic capacity of the native protein.

Trypanosoma cruzi calreticulin also binds monoglucosylated glycans (60) and participates in the maturation of cruzipain, a lysosomal protease (65) present in T. cruzi. Although TcCRT locates mainly in the ER, it is also found in the Golgi complex, reservosomes, flagellar pocket, cell surface, cytosol, nucleus, and kinetoplast $(66,67)$. However, the mechanisms involved in these diverse TcCRT localizations are unknown. Thus, TcCRT, in spite of its KEDL-ER retention sequence [KDEL in mammal CRTs (18)], translocates from the ER to the extracellular environment (Figures 1A,B) where, besides inhibiting complement (66) and acting as a virulence factor (68), it mediates antitumor effects.

In spite of the long evolutionary distance, TcCRT still shares $50 \%$ of overall sequence homology with HuCRT, reaching up to $80 \%$ in critical functional domains. Moreover, the general globular N-domain, responsible of antiangiogenic properties and the structural features of the extended arm P-domain also share structure homologies, thus announcing the possibility of functional similarities (69).

Two important TcCRT functions may explain the relationship between T. cruzi infection and cancer. First, TcCRT is an important complement inhibitor (Figure 1D) and virulence factor (Figure 1E). Second, TcCRT inhibits angiogenesis (Figure 1C). Both functions are central to inhibit tumor growth.

\section{TCCRT IS AN IMPORTANT VIRULENCE FACTOR IN T. CRUZI}

Similar to HuCRT $(70,71)$, TcCRT inhibits the complement system by interacting with C1 (Figure 1D), the first component of its classical pathway $(66,72-74)$. TcCRT is translocated from the ER to the area of flagellum emergence (Figure 1A) (66), where $\mathrm{C} 1$ is recruited by parasite-bound TcCRT and inhibited at the earliest complement activation step (C4b generation) (Figure 1D). TcCRT also affects the ability of $\mathrm{C} 1 \mathrm{~s}$ to activate $\mathrm{C} 4$, in a calcium-independent manner (74). Inhibition of $\mathrm{C} 1$ is a significant complement evasion strategy, with consequences in the host-parasite relationships. Although HuCRT and TcCRT prevent binding of the serine proteases to $\mathrm{Clq}$, they do not displace the serine proteases from the preformed stabilized $\mathrm{C} 1$ $\left(\mathrm{C} 1 \mathrm{q}, \mathrm{r}_{2}\right.$, and $\mathrm{s}_{2}$ ) complex (74). TcCRT also binds to MBL and 
Ficolins (75). C1, MBL, and Ficolins are three complement "danger signal" recognition macromolecular modules present in plasma. These molecular complexes are genetically, structurally, and functionally related, but they differ in the nature of the recognized danger signals (76). More recently, we have proposed that L-Ficolin binds TcCRT, inhibiting the lectin pathway. This inhibition may represent other $T$. cruzi strategy to inhibit the host immune response (75). In agreement with these findings, TcCRT is present on the parasite surface co-localizing with C1q (66).

Human CRT is also a membrane receptor for $\mathrm{Clq}$ [cClqR (77)], and it may bridge TcCRT on the parasite surface with HuCRT present on the host cell (Figure 1E) (78). The TcCRT/ C1q/HuCRT synapsis represents the culmination of an important molecular mimicry strategy. Apoptotic cells to be phagocytized use a similar mechanism $(34,36,37)$. The CRT/C1q complex is recognized as an "eat me" signal by $\mathrm{cClqR}$ on phagocytes. This signal is also used by T. cruzi as an "apoptotic mimicry" strategy (i.e., by capturing $\mathrm{C} 1$ in the area of flagellum emergence), thus facilitating the invasion/infectivity of host cells (79). This TcCRTC1q-mediated parasite infectivity correlates with significant increases in TcCRT mRNA levels during early (cell contact and penetration) infection stages $(36,66,68,69,72,79)$. The TcCRT$\mathrm{C} 1 \mathrm{q}$ interaction can be prevented with anti-TcCRT $\mathrm{F}\left(\mathrm{ab}^{\prime}\right)_{2}$ fragments (devoid of the C1-binding Fc domains) (80). Indeed, passive immunization of mice with these fragments decreases infectivity (68). Congenital transmission is an important T. cruzi transmission pathway. Human pregnancy is a condition of elevated circulating CRT $(81,82)$. Moreover, human placenta expresses high CRT levels (83). We have recently proposed that the TcCRT/C1q/HuCRT interaction is very important in an ex vivo model of infection of human placenta (84), indicating a possible mechanism to explain the congenital transmission.

\section{TCCRT PARTICIPATES IN THE INHIBITION OF TUMOR GROWTH}

Cancer is omnipresent in human history, and it also affects most of the living animal species, as a natural phenomenon of sporadic cellular dysfunction. Mammary, prostate, lung, cervix/uterine are just a few examples of cancer that, taken together, have epidemic proportions.

Interestingly, in patients infected with T. cruzi, cancer is rare $(10,12)$. About 80 years ago, Roskin, Ekzempliarskaia, and Klyuyeva, researchers from the former Soviet Union, postulated an experimental anticancer toxic activity derived from this infection. When they inoculated T. cruzi extracts, directly in a peritumoral area, in different tumors, both in experimental animals and in humans, similar results related to reduction of tumor size were obtained $(10-13,85,86)$. More recently, the parasite capacity to infect preferentially tumor cells, as compared to normal host cells, was described (8). Although, in general, these data suggest an antagonism between T. cruzi infection and tumor growth (8), and research progress in these areas was seriously hampered by the intense international political problems of those years (i.e., the Cold War) (11). Although several publications on these issues have appeared during the last decades, the molecular basis of this phenomenon has remained elusive.

We propose that TcCRT is an important mediator of the antitumor effects of T. cruzi infection. Similar to HuCRT, TcCRT is antiangiogenic in in vitro, ex vivo, and in vivo models (Figure 1C) $(3,87,88)$. Moreover, TcCRT inhibits the growth of a mammary adenocarcinoma and a melanoma in different experimental animal models $(3,87-89)$. The inhibition of tumor angiogenesis was proposed as a cancer therapy almost 40 years ago (90). For this reason, molecules or drugs with capacity to inhibit angiogenesis are currently applicable to a wide variety of tumors, often as a complement to other therapies (91).

Trypanosoma cruzi calreticulin and its N-terminal domain (N-TcCRT) were studied in different experimental set ups in mammals, Homo sapiens included (3). Thus, rTcCRT and its $\mathrm{N}$-TcCRT inhibit capillary growth ex vivo in Rattus rattus aortic rings, morphogenesis, proliferation, and chemotaxis in human umbilical cord endothelial cells (HUVECs) (3) and in vivo angiogenesis in the Gallus gallus chorioallantoid membrane (CAM) assay (87). TcCRT was overall more effective, in molar terms, than HuCRT (3). Interestingly, in the CAM assay, the antiangiogenic TcCRT effect was fully reverted by polyclonal antibodies against rTcCRT (88).

In agreement with the previously described facts, the in vivo antitumor capacity of $T$. cruzi infection is paralleled by the inoculation of rTcCRT, with inhibits by $60-70 \%$ the time-course development of a murine mammary methotrexate multiresistant adenocarcinoma (TA3-MTX-R) (7).

\section{T. CRUZI INFECTS NEOPLASTIC CELLS AND PROMOTES AN IMMUNE RESPONSE}

Native TcCRT (nTcCRT) on the parasite contacts ECs, mediating internalization of T. cruzi and inhibition of tumor growth. This nTcCRT/EC contact may be indirect, mediated by $\mathrm{Clq}$ (Figure 1E) or by direct binding to scavenger receptors (SRs) (Figure 1F). TcCRT has affinity for collagenous structures, a possible explanation for its binding to human $\mathrm{C} 1$ and to SRs $(66,68)$. Fluid-phase Fucoidan, bearing extensive collagen-like sequences, inhibits the binding of CRT to SR-A present on both phagocytic cells (92) and the internalization of TcCRT by ECs (3).

\section{IS NATIVE TCCRT RESPONSIBLE FOR THE ANTITUMOR EFFECT OF T. CRUZI INFECTION?}

Recombinant TcCRT has important in vivo antiangiogenic and antitumor activities $(3,88)$. The antitumor effect of T. cruzi extract has been recently reproduced in a rat model. Experimental animals showed a strong cytotoxic response against tumor, with activation of $\mathrm{CD}^{+}$and $\mathrm{CD} 8^{+} \mathrm{T}$ cells and splenocytes. Moreover, a humoral adaptive immune response is generated. These antiT. cruzi antibodies cross-reacted with tumor cells, inducing an antibody-dependent cellular toxicity in vitro (93). In a mouse model, we have reverted the antitumor effect of a T. cruzi epimastigote extract with specific antibodies against rTcCRT. Moreover, 
anti-rTcCRT $\mathrm{F}\left(\mathrm{ab}^{\prime}\right)_{2}$ antibodies (devoid of their capacity to interact with $\mathrm{C} 1$ ) neutralize the antitumor activity of $T$. cruzi infection, thus identifying nTcCRT as a mediator of this effect (unpublished data).

\section{HOW DOES TCCRT INHIBIT TUMOR GROWTH IN INDIVIDUALS INFECTED WITH T. CRUZI?}

We propose that, during T. cruzi infection, nTcCRT mediates key alterations in the tumor cell microenvironment leading to an adaptive immune response, with significant antitumor effects. Once in the circulation, T. cruzi must swiftly invade ECs (Figures 1E,F). Translocated-exteriorized TcCRT (Figures 1A,B) (92) will recruit and inactivate plasma complement C1 (Figure 1D) and inhibits angiogenesis (Figure 1C). This will allow the parasite to contact ECs via cC1qR (Figure 1E) $(77,94)$. Otherwise, the chaperone protein could interact directly with SR-A1 on ECs (Figure 1F) (95-97). Both pathways may lead to antiangiogenesis and generate a stressful environment where tumor cells will externalize their CRT, as previously shown with other stressing agents, such as Antracyclins (37). C1 recruitment and increased tumor cell phagocytosis by dendritic cells will follow (Figure 1H).

On the other hand, an adaptive immune response may be invoked by inoculated TcCRT or by its native counterpart timely externalized by infecting trypomastigotes (66) or present in epimastigote extracts (75). The chaperone protein should reach the surface of tumor cells (or ECs), thus generating a site for $\mathrm{C} 1$ binding (Figure 1G), followed by phagocytosis of these complexes by dendritic cells (Figure 1H). Targeting these activities on tumor cells should be favored by the parasite tropism for these tissues. The relevant novelty of parasite TcCRT is its difference in amino acidic sequence with the mammal (murine, in this case) counterpart. This difference may reach $50 \%$, while mammal CRTs differ among them by no more than $10 \%$ (73). Upon arrival to the regional lymph nodes, these dendritic cells will present antigenic peptides derived from TcCRT, thus activating cytotoxic T lymphocytes, among other possibilities. Whether tumor cells can cross-present peptides derived from endocytosed TcCRT to cytotoxic T cells (Figure 1I) is a matter of current research in our laboratory. Activated cytotoxic $\mathrm{T}$ cells should then return to the tumor site and act against neoplastic tumor cells. Activation of $\mathrm{CD}^{+}$ T cells via MHC II presentation, with stimulation of B cells and resulting ADCC against tumor cells, is a possibility that should also be entertained.

\section{REFERENCES}

1. Yoshida N. Molecular basis of mammalian cell invasion by Trypanosoma cruzi. An Acad Bras Cienc (2006) 78:87-111. doi:10.1590/S0001-37652006000100010

2. Oikonomopoulou K, Brinc D, Hadjisavvas A, Christofi G, Kyriacou K, Diamandis EP. The bifacial role of helminths in cancer: involvement of immune and non-immune mechanisms. Crit Rev Clin Lab Sci (2014) 51:138-48. doi:10.3109/10408363.2014.886180

3. Lopez NC, Valck C, Ramirez G, Rodriguez M, Ribeiro C, Orellana J, et al. Antiangiogenic and antitumor effects of Trypanosoma cruzi Calreticulin. PLoS Negl Trop Dis (2010) 4:e730. doi:10.1371/journal.pntd.0000730
In our murine models, these antitumor effects are better performed by TcCRT, as compared to HuCRT. Among mammals, CRTs are at least 95\% homologous in amino acidic differences. CRT immunogenicity across mammal species is thus restricted. On the other hand, because of extensive evolutionary distances, TcCRT amino acidic sequence differs by $50 \%$ with its mammal counterparts. Thus, TcCRT is more capable of generating immunogenic epitopes on the surface of mammal tumors. Recently, the expression of CRT has been correlated with a favorable prognosis of cancer. The high expression of CRT on tumor cells has been associated with a high density of infiltrating mature dendritic cells and effector memory T-cell subsets, suggesting that CRT triggers the activation of an adaptive immune response in the tumor microenvironment (98). Thus, TcCRT expressed and secreted by the parasite may be also important in this regard.

\section{CONCLUDING REMARKS}

Infection with T. cruzi correlates with increased resistant to tumors. Since, during infection, nTcCRT is translocated to the parasite exterior and experimental parenteral administration of rTcCRT mimics the antitumor effects of the infection, nTcCRT is the most likely responsible molecule for these effects. Moreover, the antitumor effects of parasite infection can be specifically reverted by anti-rTcCRT antibodies. Since, in a large set of experimental animals treated with rTcCRT, no clinical deleterious effects have been detected by standard clinical veterinary criteria, we can now propose that rTcCRT or derived domains are interesting immunological tools to be considered in more advanced preclinical trials (e.g., rTcCRT capacity to bind to human mammary tumor cell lines in vitro, to subsequently incorporate $\mathrm{C} 1$, with increased capacity to induce phagocytosis).

\section{AUTHOR CONTRIBUTIONS}

GR-T, PA, and AF designed experiments. GR-T and PA performed experiments. GR-T, PA, and AF interpreted the data. GR-T, PA, and AF generated key reagents. GR-T, PA, and AF wrote, revised, and edited the manuscript. GR-T, PA, and AF approved the manuscript.

\section{FUNDING}

This work was supported by CONICYT-CHILE grants: FONDECYT Regular 1130099 and FONDECYT-Iniciación 11110251.

4. Coura JR, Vinas PA. Chagas disease: a new worldwide challenge. Nature (2010) 465:S6-7. doi:10.1038/nature09221

5. Perez-Molina JA, Perez AM, Norman FF, Monge-Maillo B, Lopez-Velez R. Old and new challenges in Chagas disease. Lancet Infect Dis (2015) 15:1347-56. doi:10.1016/S1473-3099(15)00243-1

6. Tanowitz HB, Weiss LM, Montgomery SP. Chagas disease has now gone global. PLoS Negl Trop Dis (2011) 5:e1136. doi:10.1371/journal.pntd.0001136

7. Ramirez-Toloza G, Aguilar-Guzman L, Valck C, Abello P, Ferreira A. Is it all that bad when living with an intracellular protozoan? The role of Trypanosoma cruzi calreticulin in angiogenesis and tumor growth. Front Oncol (2014) 4:382. doi: 10.3389/fonc.2014.00382 
8. Kallinikova VD, Matekin PV, Ogloblina TA, Leikina MI, Kononenko AF, Sokolova NM, et al. [Anticancer properties of flagellate protozoan Trypanosoma cruzi Chagas, 1909]. Izv Akad Nauk Ser Biol (2001) 3:299-311.

9. Oliveira EC, Leite MS, Miranda JA, Andrade AL, Garcia SB, Luquetti AO, et al. Chronic Trypanosoma cruzi infection associated with low incidence of 1,2-dimethylhydrazine-induced colon cancer in rats. Carcinogenesis (2001) 22:737-40. doi:10.1093/carcin/22.5.737

10. Klyuyeva NG, Roskin GI. Biotherapy of Malignant Tumours. New York: Pergamon Press (1963). 315 p.

11. Krementsov NL. The Cure: A Story of Cancer and Politics from the Annals of the Cold War. Chicago: University of Chicago Press (2002). 261 p.

12. Roskin G. Toxin therapy of experimental cancer; the influence of protozoan infections upon transplanted cancer. Cancer Res (1946) 6:363-5.

13. Hauschka TS, Goodwin MB. Trypanosoma cruzi Endotoxin (KR) in the treatment of malignant mouse tumors. Science (1948) 107:600-2. doi:10.1126/ science.107.2788.600

14. Folkman J. Fundamental concepts of the angiogenic process. Curr Mol Med (2003) 3:643-51. doi:10.2174/1566524033479465

15. Junqueira C, Santos LI, Galvao-Filho B, Teixeira SM, Rodrigues FG, DaRocha WD, et al. Trypanosoma cruzi as an effective cancer antigen delivery vector. Proc Natl Acad Sci U S A (2011) 108:19695-700. doi:10.1073/pnas.1110030108

16. Sanchez Valdez FJ, Perez Brandan C, Zago MP, Labriola C, Ferreira A, Basombrio MA. Trypanosoma cruzi carrying a monoallelic deletion of the calreticulin (TcCRT) gene are susceptible to complement mediated killing and defective in their metacyclogenesis. Mol Immunol (2013) 53:198-205. doi:10.1016/j.molimm.2012.08.001

17. Sanchez-Valdez FJ, Perez Brandan C, Ramirez G, Uncos AD, Zago MP, Cimino RO, et al. A monoallelic deletion of the TcCRT gene increases the attenuation of a cultured Trypanosoma cruzi strain, protecting against an in vivo virulent challenge. PLoS Negl Trop Dis (2014) 8:e2696. doi:10.1371/ journal.pntd.0002696

18. Michalak M, Groenendyk J, Szabo E, Gold LI, Opas M. Calreticulin, a multi-process calcium-buffering chaperone of the endoplasmic reticulum. Biochem J (2009) 417:651-66. doi:10.1042/BJ20081847

19. Lu YC, Weng WC, Lee H. Functional roles of calreticulin in cancer biology. Biomed Res Int (2015) 2015:526524. doi:10.1155/2015/526524

20. Michalak M, Milner RE, Burns K, Opas M. Calreticulin. Biochem J (1992) 285(Pt 3):681-92. doi:10.1042/bj2850681

21. Michalak M, Corbett EF, Mesaeli N, Nakamura K, Opas M. Calreticulin: one protein, one gene, many functions. Biochem J (1999) 344(Pt 2):281-92. doi:10.1042/0264-6021:3440281

22. Baksh S, Michalak M. Expression of calreticulin in Escherichia coli and identification of its Ca2+ binding domains. J Biol Chem (1991) 266:21458-65.

23. Arias I, Sepulveda C, Bravo P, Hamilton-West C, Maldonado I, Ferreira A. Comparative effect of human and Trypanosoma cruzi calreticulin in wound healing. J Tissue Eng Regen Med (2012) 9(1):41-54. doi:10.1002/term.1613

24. Gold LI, Rahman M, Blechman KM, Greives MR, Churgin S, Michaels J, et al. Overview of the role for calreticulin in the enhancement of wound healing through multiple biological effects. J Investig Dermatol Symp Proc (2006) 11:57-65. doi:10.1038/sj.jidsymp.5650011

25. Nanney LB, Woodrell CD, Greives MR, Cardwell NL, Pollins AC, Bancroft TA, et al. Calreticulin enhances porcine wound repair by diverse biological effects. Am J Pathol (2008) 173:610-30. doi:10.2353/ajpath.2008.071027

26. Burns K, Duggan B, Atkinson EA, Famulski KS, Nemer M, Bleackley RC, et al. Modulation of gene expression by calreticulin binding to the glucocorticoid receptor. Nature (1994) 367:476-80. doi:10.1038/367476a0

27. Dedhar S, Rennie PS, Shago M, Hagesteijn CY, Yang H, Filmus J, et al. Inhibition of nuclear hormone receptor activity by calreticulin. Nature (1994) 367:480-3. doi:10.1038/367480a0

28. Holaska JM, Black BE, Love DC, Hanover JA, Leszyk J, Paschal BM. Calreticulin is a receptor for nuclear export. J Cell Biol (2001) 152:127-40. doi:10.1083/jcb.152.1.127

29. Iakova P, Wang GL, Timchenko L, Michalak M, Pereira-Smith OM, Smith JR, et al. Competition of CUGBP1 and calreticulin for the regulation of p21 translation determines cell fate. EMBO J (2004) 23:406-17. doi:10.1038/ sj.emboj. 7600052

30. Nickenig G, Michaelsen F, Muller C, Berger A, Vogel T, Sachinidis A, et al. Destabilization of AT(1) receptor mRNA by calreticulin. Circ Res (2002) 90:53-8. doi:10.1161/hh0102.102503
31. Singh NK, Atreya CD, Nakhasi HL. Identification of calreticulin as a rubella virus RNA binding protein. Proc Natl Acad Sci U S A (1994) 91:12770-4. doi:10.1073/pnas.91.26.12770

32. Timchenko LT, Iakova P, Welm AL, Cai ZJ, Timchenko NA. Calreticulin interacts with C/EBPalpha and C/EBPbeta mRNAs and represses translation of C/EBP proteins. Mol Cell Biol (2002) 22:7242-57. doi:10.1128/ MCB.22.20.7242-7257.2002

33. Totary-Jain H, Naveh-Many T, Riahi Y, Kaiser N, Eckel J, Sasson S. Calreticulin destabilizes glucose transporter-1 mRNA in vascular endothelial and smooth muscle cells under high-glucose conditions. Circ Res (2005) 97:1001-8. doi:10.1161/01.RES.0000189260.46084.e5

34. Obeid M, Panaretakis T, Joza N, Tufi R, Tesniere A, van Endert P, et al. Calreticulin exposure is required for the immunogenicity of gammairradiation and UVC light-induced apoptosis. Cell Death Differ (2007) 14:1848-50. doi:10.1038/sj.cdd.4402201

35. Obeid M, Panaretakis T, Tesniere A, Joza N, Tufi R, Apetoh L, et al. Leveraging the immune system during chemotherapy: moving calreticulin to the cell surface converts apoptotic death from "silent" to immunogenic. Cancer Res (2007) 67:7941-4. doi:10.1158/0008-5472.CAN-07-1622

36. Obeid M, Tesniere A, Ghiringhelli F, Fimia GM, Apetoh L, Perfettini JL, et al. Calreticulin exposure dictates the immunogenicity of cancer cell death. Nat Med (2007) 13:54-61. doi:10.1038/nm1523

37. Obeid M, Tesniere A, Panaretakis T, Tufi R, Joza N, van Endert P, et al. Ectocalreticulin in immunogenic chemotherapy. Immunol Rev (2007) 220:22-34. doi:10.1111/j.1600-065X.2007.00567.x

38. Tesniere A, Apetoh L, Ghiringhelli F, Joza N, Panaretakis T, Kepp O, et al. Immunogenic cancer cell death: a key-lock paradigm. Curr Opin Immunol (2008) 20:504-11. doi:10.1016/j.coi.2008.05.007

39. Gardai SJ, McPhillips KA, Frasch SC, Janssen WJ, Starefeldt A, MurphyUllrich JE, et al. Cell-surface calreticulin initiates clearance of viable or apoptotic cells through trans-activation of LRP on the phagocyte. Cell (2005) 123:321-34. doi:10.1016/j.cell.2005.08.032

40. Zamanian M, Veerakumarasivam A, Abdullah S, Rosli R. Calreticulin and cancer. Pathol Oncol Res (2013) 19:149-54. doi:10.1007/s12253-012-9600-2

41. Chen CN, Chang CC, Su TE, Hsu WM, Jeng YM, Ho MC, et al. Identification of calreticulin as a prognosis marker and angiogenic regulator in human gastric cancer. Ann Surg Oncol (2009) 16:524-33. doi:10.1245/s10434-008-0243-1

42. Lwin ZM, Guo C, Salim A, Yip GW, Chew FT, Nan J, et al. Clinicopathological significance of calreticulin in breast invasive ductal carcinoma. Mod Pathol (2010) 23:1559-66. doi:10.1038/modpathol.2010.173

43. Eggleton P, Bremer E, Dudek E, Michalak M. Calreticulin, a therapeutic target? Expert Opin Ther Targets (2016) 25:1-11. doi:10.1517/14728222.2016. 1164695

44. Yao L, Pike SE, Tosato G. Laminin binding to the calreticulin fragment vasostatin regulates endothelial cell function. J Leukoc Biol (2002) 71:47-53.

45. Pike SE, Yao L, Jones KD, Cherney B, Appella E, Sakaguchi K, et al. Vasostatin, a calreticulin fragment, inhibits angiogenesis and suppresses tumor growth. J Exp Med (1998) 188:2349-56. doi:10.1084/jem.188.12.2349

46. Pike SE, Yao L, Setsuda J, Jones KD, Cherney B, Appella E, et al. Calreticulin and calreticulin fragments are endothelial cell inhibitors that suppress tumor growth. Blood (1999) 94:2461-8.

47. Cai KX, Tse LY, Leung C, Tam PK, Xu R, Sham MH. Suppression of lung tumor growth and metastasis in mice by adeno-associated virus-mediated expression of vasostatin. Clin Cancer Res (2008) 14:939-49. doi:10.1158/1078-0432. CCR-07-1930

48. Jazowiecka-Rakus J, Jarosz M, Kozlowska D, Sochanik A, Szala S. Combination of vasostatin and cyclophosphamide in the therapy of murine melanoma tumors. Acta Biochim Pol (2007) 54:125-33.

49. Yao L, Pike SE, Pittaluga S, Cherney B, Gupta G, Jaffe ES, et al. Anti-tumor activities of the angiogenesis inhibitors interferon-inducible protein-10 and the calreticulin fragment vasostatin. Cancer Immunol Immunother (2002) 51:358-66. doi:10.1007/s00262-002-0294-2

50. Shu Q, Li W, Li H, Sun G. Vasostatin inhibits VEGF-induced endothelial cell proliferation, tube formation and induces cell apoptosis under oxygen deprivation. Int J Mol Sci (2014) 15:6019-30. doi:10.3390/ijms15046019

51. McCauliffe DP, Zappi E, Lieu TS, Michalak M, Sontheimer RD, Capra JD. A human Ro/SS-A autoantigen is the homologue of calreticulin and is highly homologous with onchocercal RAL-1 antigen and an aplysia "memory molecule". J Clin Invest (1990) 86:332-5. doi:10.1172/JCI114704 
52. Ferreira CA, Da Silva Vaz I, da Silva SS, Haag KL, Valenzuela JG, Masuda A. Cloning and partial characterization of a Boophilus microplus (Acari: Ixodidae) calreticulin. Exp Parasitol (2002) 101:25-34. doi:10.1016/S00144894(02)00032-2

53. Smith MJ. Nucleotide sequence of a drosophila melanogaster gene encoding a calreticulin homologue. DNA Seq (1992) 3:247-50. doi:10.3109/10425 179209034025

54. Kasper G, Brown A, Eberl M, Vallar L, Kieffer N, Berry C, et al. A calreticulin-like molecule from the human hookworm Necator americanus interacts with $\mathrm{C} 1 \mathrm{q}$ and the cytoplasmic signalling domains of some integrins. Parasite Immunol (2001) 23:141-52. doi:10.1046/j.1365-3024.2001.00366.x

55. Khalife J, Pierce RJ, Godin C, Capron A. Cloning and sequencing of the gene encoding Schistosoma mansoni calreticulin. Mol Biochem Parasitol (1993) 62:313-5. doi:10.1016/0166-6851(93)90120-M

56. Rokeach LA, Zimmerman PA, Unnasch TR. Epitopes of the Onchocerca volvulus RAL1 antigen, a member of the calreticulin family of proteins, recognized by sera from patients with onchocerciasis. Infect Immun (1994) 62:3696-704.

57. Smith MJ. A C. elegans gene encodes a protein homologous to mammalian calreticulin. DNA Seq (1992) 2:235-40. doi:10.3109/10425179209020808

58. Aguillon JC, Ferreira L, Perez C, Colombo A, Molina MC, Wallace A, et al. Tc45, a dimorphic Trypanosoma cruzi immunogen with variable chromosomal localization, is calreticulin. Am J Trop Med Hyg (2000) 63:306-12.

59. Joshi M, Pogue GP, Duncan RC, Lee NS, Singh NK, Atreya CD, et al. Isolation and characterization of Leishmania donovani calreticulin gene and its conservation of the RNA binding activity. Mol Biochem Parasitol (1996) 81:53-64. doi:10.1016/0166-6851(96)02676-X

60. Labriola C, Cazzulo JJ, Parodi AJ. Trypanosoma cruzi calreticulin is a lectin that binds monoglucosylated oligosaccharides but not protein moieties of glycoproteins. Mol Biol Cell (1999) 10:1381-94. doi:10.1091/mbc.10.5.1381

61. Oladiran A, Belosevic M. Trypanosoma carassii calreticulin binds host complement component $\mathrm{C} 1 \mathrm{q}$ and inhibits classical complement pathway-mediated lysis. Dev Comp Immunol (2010) 34:396-405. doi:10.1016/j.dci.2009.11.005

62. Denecke J, Carlsson LE, Vidal S, Hoglund AS, Ek B, van Zeijl MJ, et al. The tobacco homolog of mammalian calreticulin is present in protein complexes in vivo. Plant Cell (1995) 7:391-406. doi:10.1105/tpc.7.4.391

63. Jaworski DC, Higgins JA, Radulovic S, Vaughan JA, Azad AF. Presence of calreticulin in vector fleas (Siphonaptera). J Med Entomol (1996) 33:482-9. doi:10.1093/jmedent/33.3.482

64. Marcelain K, Colombo A, Molina MC, Ferreira L, Lorca M, Aguillon JC, et al. Development of an immunoenzymatic assay for the detection of human antibodies against Trypanosoma cruzi calreticulin, an immunodominant antigen. Acta Trop (2000) 75:291-300. doi:10.1016/S0001-706X(00)00062-0

65. Conte I, Labriola C, Cazzulo JJ, Docampo R, Parodi AJ. The interplay between folding-facilitating mechanisms in Trypanosoma cruzi endoplasmic reticulum. Mol Biol Cell (2003) 14:3529-40. doi:10.1091/mbc.E03-04-0228

66. Ferreira V, Valck C, Sanchez G, Gingras A, Tzima S, Molina MC, et al. The classical activation pathway of the human complement system is specifically inhibited by calreticulin from Trypanosoma cruzi. J Immunol (2004) 172:3042-50. doi:10.4049/jimmunol.172.5.3042

67. Souto-Padron T, Labriola CA, de Souza W. Immunocytochemical localisation of calreticulin in Trypanosoma cruzi. Histochem Cell Biol (2004) 122:563-9. doi:10.1007/s00418-004-0724-7

68. Ramirez G, Valck C, Molina MC, Ribeiro CH, Lopez N, Sanchez G, et al. Trypanosoma cruzi calreticulin: a novel virulence factor that binds complement $\mathrm{C} 1$ on the parasite surface and promotes infectivity. Immunobiology (2011) 216:265-73. doi:10.1016/j.imbio.2010.04.001

69. Ramirez G, Valck C, Ferreira VP, Lopez N, Ferreira A. Extracellular Trypanosoma cruzi calreticulin in the host-parasite interplay. Trends Parasitol (2011) 27:115-22. doi:10.1016/j.pt.2010.12.007

70. Stuart GR, Lynch NJ,DayAJ,Schwaeble WJ, Sim RB. The C1q and collectin binding site within C1q receptor (cell surface calreticulin). Immunopharmacology (1997) 38:73-80. doi:10.1016/S0162-3109(97)00076-3

71. Stuart GR, Lynch NJ, Lu J, Geick A, Moffatt BE, Sim RB, et al. Localisation of the C1q binding site within C1q receptor/calreticulin. FEBS Lett (1996) 397:245-9. doi:10.1016/S0014-5793(96)01156-8

72. Ferreira V, Molina MC, Schwaeble W, Lemus D, Ferreira A. Does Trypanosoma cruzi calreticulin modulate the complement system and angiogenesis? Trends Parasitol (2005) 21:169-74. doi:10.1016/j.pt.2005.02.005
73. Ferreira V, Molina MC, Valck C, Rojas A, Aguilar L, Ramirez G, et al. Role of calreticulin from parasites in its interaction with vertebrate hosts. Mol Immunol (2004) 40:1279-91. doi:10.1016/j.molimm.2003.11.018

74. Valck C, Ramirez G, Lopez N, Ribeiro CH, Maldonado I, Sanchez G, et al. Molecular mechanisms involved in the inactivation of the first component of human complement by Trypanosoma cruzi calreticulin. Mol Immunol (2010) 47:1516-21. doi:10.1016/j.molimm.2010.01.019

75. Sosoniuk E, Vallejos G, Kenawy H, Gaboriaud C, Thielens N, Fujita T, et al. Trypanosoma cruzi calreticulin inhibits the complement lectin pathway activation by direct interaction with L-Ficolin. Mol Immunol (2014) 60:80-5. doi:10.1016/j.molimm.2014.03.014

76. Ramirez G, Valck C, Aguilar L, Kemmerling U, Lopez-Munoz R, Cabrera G, et al. Roles of Trypanosoma cruzi calreticulin in parasite-host interactions and in tumor growth. Mol Immunol (2012) 52:133-40. doi:10.1016/j.molimm. 2012.05.006

77. Eggleton P, Tenner AJ, Reid KB. C1q receptors. Clin Exp Immunol (2000) 120:406-12. doi:10.1046/j.1365-2249.2000.01218.x

78. Malhotra R. Collectin receptor (C1q receptor): structure and function. Behring Inst Mitt (1993) (93):254-61.

79. Rimoldi MT, Tenner AJ, Bobak DA, Joiner KA. Complement component C1q enhances invasion of human mononuclear phagocytes and fibroblasts by Trypanosoma cruzi trypomastigotes. JClin Invest (1989) 84:1982-9. doi:10.1172/JCI114388

80. Aguilar L, Ramirez G, Valck C, Molina MC, Rojas A, Schwaeble W, et al. $\left.\mathrm{F}(\mathrm{ab})^{\prime}\right) 2$ antibody fragments against Trypanosoma cruzi calreticulin inhibit its interaction with the first component of human complement. Biol Res (2005) 38:187-95. doi:10.4067/S0716-97602005000200008

81. Crawford KE, Kalionis B, Stevenson JL, Brennecke SP, Gude NM. Calreticulin has opposing effects on the migration of human trophoblast and myometrial endothelial cells. Placenta (2012) 33:416-23. doi:10.1016/j. placenta.2012.02.003

82. Gu VY, Wong MH, Stevenson JL, Crawford KE, Brennecke SP, Gude NM. Calreticulin in human pregnancy and pre-eclampsia. Mol Hum Reprod (2008) 14:309-15. doi:10.1093/molehr/gan017

83. Houen G, Koch C. Human placental calreticulin: purification, characterization and association with other proteins. Acta Chem Scand (1994) 48:905-11. doi:10.3891/acta.chem.scand.48-0905

84. Castillo C, Ramirez G, Valck C, Aguilar L, Maldonado I, Rosas C, et al. The interaction of classical complement component $\mathrm{C} 1$ with parasite and host calreticulin mediates Trypanosoma cruzi infection of human placenta. PLoS Negl Trop Dis (2013) 7:e2376. doi:10.1371/journal.pntd.0002376

85. Hauschka T, Sake L, Rlair M. Trypanosoma cruzi in treatment of mouse tumours. J Natl Cancer Inst (1947) 7:189.

86. Malisoff WM. The action of the endotoxin of Trypanosoma cruzi (KR) on malignant mouse tumors. Science (1947) 106(2763):591-4. doi:10.1126/ science.106.2763.591-a

87. Molina MC, Ferreira V, Valck C, Aguilar L, Orellana J, Rojas A, et al. An in vivo role for Trypanosoma cruzi calreticulin in antiangiogenesis. Mol Biochem Parasitol (2005) 140:133-40. doi:10.1016/j.molbiopara.2004.12.014

88. Toledo V, Ramirez G, Valck C, Lopez N, Ribeiro CH, Maldonado I, et al. Comparative in vivo antiangiogenic effects of calreticulin from Trypanosoma cruzi and Homo sapiens sapiens. Biol Res (2010) 43:287-9. doi:10.4067/ S0716-97602010000300004

89. Aguilar-Guzman L, Lobos-Gonzalez L, Rosas C, Vallejos G, Falcon C, Sosoniuk E, et al. Human survivin and Trypanosoma cruzi calreticulin act in synergy against a murine melanoma in vivo. PLoS One (2014) 9:e95457. doi:10.1371/journal.pone.0095457

90. Baillie CT, Winslet MC, Bradley NJ. Tumour vasculature - a potential therapeutic target. Br J Cancer (1995) 72:257-67. doi:10.1038/bjc.1995.323

91. Griffioen AW, Molema G. Angiogenesis: potentials for pharmacologic intervention in the treatment of cancer, cardiovascular diseases, and chronic inflammation. Pharmacol Rev (2000) 52:237-68.

92. Berwin B, Hart JP, Rice S, Gass C, Pizzo SV, Post SR, et al. Scavenger receptor-A mediates gp96/GRP94 and calreticulin internalization by antigen-presenting cells. EMBO J (2003) 22:6127-36. doi:10.1093/emboj/cdg572

93. Ubillos L, Freire T, Berriel E, Chiribao ML, Chiale C, Festari MF, et al. Trypanosoma cruzi extracts elicit protective immune response against chemically induced colon and mammary cancers. Int J Cancer (2016) 138:1719-31. doi:10.1002/ijc.29910 
94. van den Berg RH, Faber-Krol MC, Sim RB, Daha MR. The first subcomponent of complement, C1q, triggers the production of IL-8, IL-6, and monocyte chemoattractant peptide-1 by human umbilical vein endothelial cells. J Immunol (1998) 161:6924-30.

95. Adachi H, Tsujimoto M, Arai H, Inoue K. Expression cloning of a novel scavenger receptor from human endothelial cells. J Biol Chem (1997) 272:31217-20. doi:10.1074/jbc.272.50.31217

96. Canton J, Neculai D, Grinstein S. Scavenger receptors in homeostasis and immunity. Nat Rev Immunol (2013) 13:621-34. doi:10.1038/nri3515

97. Zani IA, Stephen SL, Mughal NA, Russell D, Homer-Vanniasinkam S, Wheatcroft SB, et al. Scavenger receptor structure and function in health and disease. Cells (2015) 4:178-201. doi:10.3390/cells4020178

98. Fucikova J, Becht E, Iribarren K, Goc J, Remark R, Damotte D, et al. Calreticulin expression in human non-small cell lung cancers correlates with increased accumulation of antitumor immune cells and favorable prognosis. Cancer Res (2016) 76:1746-56. doi: 10.1158/0008-5472.CAN-15-1142

Conflict of Interest Statement: The authors declare that the research was conducted in the absence of any commercial or financial relationships that could be construed as a potential conflict of interest.

Copyright (c) 2016 Ramirez-Toloza, Abello and Ferreira. This is an open-access article distributed under the terms of the Creative Commons Attribution License (CC BY). The use, distribution or reproduction in other forums is permitted, provided the original author(s) or licensor are credited and that the original publication in this journal is cited, in accordance with accepted academic practice. No use, distribution or reproduction is permitted which does not comply with these terms. 